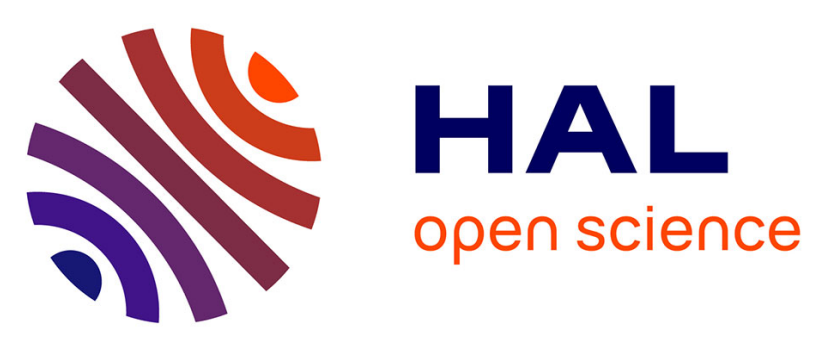

\title{
Molecular investigation of hard ticks (Acari: Ixodidae) and fleas (Siphonaptera: Pulicidae) as potential vectors of rickettsial and mycoplasmal agents
}

Sándor Hornok, Marina L. Meli, Andrea Perreten, Róbert Farkas, Barbara Willi, Frederic Beugnet, Hans Lutz, Regina Hofmann-Lehmann

\section{To cite this version:}

Sándor Hornok, Marina L. Meli, Andrea Perreten, Róbert Farkas, Barbara Willi, et al.. Molecular investigation of hard ticks (Acari: Ixodidae) and fleas (Siphonaptera: Pulicidae) as potential vectors of rickettsial and mycoplasmal agents. Veterinary Microbiology, 2009, 140 (1-2), pp.98. 10.1016/j.vetmic.2009.07.013 . hal-00535917

\section{HAL Id: hal-00535917 https://hal.science/hal-00535917}

Submitted on 14 Nov 2010

HAL is a multi-disciplinary open access archive for the deposit and dissemination of scientific research documents, whether they are published or not. The documents may come from teaching and research institutions in France or abroad, or from public or private research centers.
L'archive ouverte pluridisciplinaire HAL, est destinée au dépôt et à la diffusion de documents scientifiques de niveau recherche, publiés ou non, émanant des établissements d'enseignement et de recherche français ou étrangers, des laboratoires publics ou privés. 


\section{Accepted Manuscript}

Title: Molecular investigation of hard ticks (Acari: Ixodidae) and fleas (Siphonaptera: Pulicidae) as potential vectors of rickettsial and mycoplasmal agents

Authors: Sándor Hornok, Marina L. Meli, Andrea Perreten, Róbert Farkas, Barbara Willi, Frederic Beugnet, Hans Lutz,

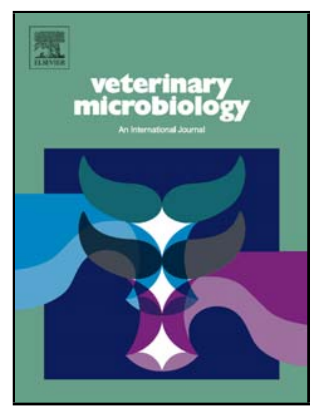
Regina Hofmann-Lehmann

PII:

DOI:

S0378-1135(09)00329-0

Reference: doi:10.1016/j.vetmic.2009.07.013

VETMIC 4499

To appear in: $\quad$ VETMIC

Received date: $\quad 28-11-2008$

Revised date: 23-4-2009

Accepted date: $\quad 3-7-2009$

Please cite this article as: Hornok, S., Meli, M.L., Perreten, A., Farkas, R., Willi, B., Beugnet, F., Lutz, H., Hofmann-Lehmann, R., Molecular investigation of hard ticks (Acari: Ixodidae) and fleas (Siphonaptera: Pulicidae) as potential vectors of rickettsial and mycoplasmal agents, Veterinary Microbiology (2008), doi:10.1016/j.vetmic.2009.07.013

This is a PDF file of an unedited manuscript that has been accepted for publication. As a service to our customers we are providing this early version of the manuscript. The manuscript will undergo copyediting, typesetting, and review of the resulting proof before it is published in its final form. Please note that during the production process errors may be discovered which could affect the content, and all legal disclaimers that apply to the journal pertain. 
4

\section{Molecular investigation of hard ticks (Acari: Ixodidae) and fleas}

(Siphonaptera: Pulicidae) as potential vectors of

$$
\text { rickettsial and mycoplasmal agents }
$$

$$
{ }^{1} \text { Department of Parasitology and Zoology, }
$$

Faculty of Veterinary Science, Szent István University, 1078-Budapest, Hungary

1

${ }^{2}$ Clinical Laboratory and ${ }^{3}$ Clinic for Small Animal Internal Medicine, Vetsuisse Faculty,

$$
{ }^{4} \text { Merial SAS, } 29 \text { Av Tony Garnier, } 69007 \text { Lyon, France }
$$

* Corresponding author. Tel.: 36-1-478-4187, Fax: 36-1-478-4193; E-mail address:

\section{Hornok.Sandor@aotk.szie.hu}

\section{ABSTRACT}

The aim of the present study was twofold. First, in general, to reveal new aspects of the potential vector role of ixodid ticks and fleas by screening large numbers of specimens with recently developed molecular biological methods. Second, to evaluate the occurrence of vector-borne infectious agents in a geographical context. Altogether 3,442 unfed hard ticks (Ixodes ricinus, Dermacentor marginatus, D. reticulatus, Haemaphysalis inermis, H. 
concinna, H. punctata) and 939 fleas of cats and dogs (Ctenocephalides felis, C. canis, Pulex irritans) were collected in Hungary. DNA was extracted and analyzed in pools for representatives of the orders Rickettsiales and Mycoplasmatales.

H. inermis was newly identified as the most important potential vector for Rickettsia helvetica in the study region. A novel Rickettsia genotype (designated 'Candidatus R. hungarica') was also detected in the same tick species, with a maximum of $95.8 \%$ glt $A$ gene sequence identity to known rickettsiae. In addition, $P$. irritans tested positive for Rickettsia sp. RF2125, which has not been previously described in Europe. The human pathogen R. felis and the feline pathogen 'Candidatus Mycoplasma turicensis' were shown for the first time to occur in Central-Eastern Europe. Further novel findings include the presence of Spiroplasma spp. in D. marginatus and fleas.

In conclusion, this molecular study extends the geographic range and vector spectrum of several arthropod-borne agents, some of which have zoonotic potential.

\section{Keywords: rickettsia; Ehrlichia canis; haemotropic mycoplasma; spiroplasma; tick; flea}

\section{Introduction}

$$
\text { Blood-sucking arthropod vectors, exemplified by ticks and fleas, are able to transmit }
$$
infectious agents between animals and/or humans. Most of the pathogenic bacteria belonging to the order Rickettsiales are vector-borne (Dumler et al., 2001), and this transmission route has also been suggested for several representatives of the order Mycoplasmatales (Neimark et al., 2001).

Rickettsia spp. (family Rickettsiaceae, order Rickettsiales) are Gram-negative, obligate intracellular bacteria (Dumler et al., 2001). Although they have been long known for their public health importance, recently an emerging veterinary significance of various species was 
also recognized (Hechemy et al., 2006). Similarly, Ehrlichia spp. (familiy Anaplasmataceae, order Rickettsiales) include both human and animal pathoges (Dumler at al., 2001).

Haemotropic mycoplasmas (also known as haemoplasmas; order Mycoplasmatales), formerly assigned to the genera Haemobartonella and Eperythrozoon (Neimark et al., 2001), attach to red blood cells. This may lead to haemolytic anaemia in infected domestic and wild animals. Vectors of haemoplasmas may include fleas, hard ticks, and mosquitoes (Neimark et al., 2001).

Spiroplasma spp. are helical mycoplasmas. Although they have been implicated in spongiform encephalopathies (Bastian et al., 2007), unambiguous information on their exact role in diseases is still lacking. Various categories of insects and arachnids, including certain hard ticks, such as I. ricinus, have been shown to harbor these bacteria (Carle et al., 1995).

In Hungary Rickettsia slovaca-like organisms have been found in questing (unfed) Dermacentor spp. (Rehácek et al., 1979). More recently engorged ticks were investigated: $R$. helvetica and R. monacensis have been detected in I. ricinus, $R$. raoultii (formerly Rickettsia sp. RpA4) in D. reticulatus, and a distinct rickettsia genotype in Haemaphysalis concinna (Sréter-Lancz et al., 2006). However, no other tick species - particularly not questing ones or flea species have been evaluated. Similarly, no data have been published to date on the occurrence of Ehrlichia canis, haemotropic Mycoplasma, or Spiroplasma spp. in ticks or fleas of this region in Europe. Therefore, the present study was undertaken to obtain relevant and updated information on these important vector-borne agents.

\section{Materials and methods}

\subsection{Origin of the samples}


Between March and July 2007, a total of 3,442 hard ticks (Acari: Ixodidae) were collected from vegetation at 37 locations in Hungary using the cloth-dragging and flagging method. The species, stage, and sex of the ticks were determined by microscopic examination. Subsequently, ticks were allotted into pools (Table 1) taking into account their size, i.e. for optimal DNA extraction. The last pool of each species contained the remainder of specimens.

In addition, 939 fleas (Siphonaptera: Pulicidae) were collected - 420 from cats and 519 from dogs - at 14 small animal clinics in various parts of the country. All fleas of one species removed from one animal were pooled (Table 1). Ctenocephalides felis were obtained from cats, C. canis from cats and dogs, and Pulex irritans from dogs. Both tick and flea samples were stored in $70 \%$ ethanol until molecular biological analysis.

\subsection{DNA extraction}

Pools of ticks and fleas were air-dried, washed twice in phosphate-buffered saline without $\mathrm{MgCl}_{2}$ or $\mathrm{CaCl}_{2}$ (DPBS; Invitrogen, Basel, Switzerland) and minced with scissors in $100 \mu 1$ DPBS at the bottom of $2 \mathrm{ml}$ Eppendorf tubes. Between the preparations of pools, the scissors were decontaminated by washing in tap water, burning, and cooling in distilled water.

From all tick pools and from those of $C$. canis and P. irritans, DNA was extracted using the MagNA Pure LC total nucleic acid isolation kit (Roche Diagnostics, Rotkreuz, Switzerland). Briefly, $150 \mu \mathrm{l}$ of DPBS and $375 \mu$ of lysis buffer containing guanidinium thiocyanate and Triton X-100 were added to each pool, together with a $5 \mathrm{~mm}$ stainless steel bead (Schieritz and Hauenstein AG, Arlesheim, Switzerland). The samples were homogenized in a Mixer Mill device (Retsch GmbH, Haan, Germany) for 2 min at 30,000 Hz. After a short centrifugation at 5,000 $g, 500 \mu l$ of the supernatant from each sample was loaded onto the MagNA Pure LC Instrument (Roche Diagnostics). Two negative extraction controls 
102 containing only DPBS were included per 30 samples in order to monitor for cross-

103 contamination. DNA from the 187 pools of $C$. felis was extracted using the QIAamp DNA mini kit (QIAGEN, Hilden, Germany). In both procedures the elution volume was $100 \mu 1$. and typhus group rickettsiae (Boretti et al., in press).

\subsection{Real-time PCRS}

All samples were first screened with real-time PCR. Cycling conditions were: $50^{\circ} \mathrm{C}$ for $2 \mathrm{~min}$ and $95{ }^{\circ} \mathrm{C}$ for $10 \mathrm{~min}$, followed by 45 cycles of $95{ }^{\circ} \mathrm{C}$ for $15 \mathrm{~s}$ and $60{ }^{\circ} \mathrm{C}$ for $1 \mathrm{~min}$. Ninety three samples (including three negative extraction controls) were analyzed in one assay, together with two - external and internal - negative and one positive PCR controls. The tests were performed using either the ABI Prism 7500 (for Rickettsia spp.) or 7700 (for all others) Sequence Detection Systems (Applied Biosystems).

\subsubsection{TaqMan PCRs for Rickettsia spp.}

First an assay that amplifies a 65-bp portion of the 23S rRNA gene of $R$. helvetica was performed. Then all samples negative in the $23 \mathrm{~S}$ rRNA PCR (or chosen for confirmatory analysis) were tested with TaqMan PCR for a 74-bp fragment of the gltA gene in spotted fever 


\subsubsection{TaqMan PCR for Ehrlichia canis}

127

128 This method to detect a portion of the 16S rRNA gene of E. canis was performed as described

129 previously (Foley et al., 2007).

130

2.3.3. Universal SYBR Green PCR for haemotropic mycoplasmas

132

133 The assay served to screen all DNA samples for the presence of haemotropic mycoplasmas

134 (Willi et al., submitted for publication). In brief, the reaction volume was $25 \mu$, consisting of

$13512.5 \mu \mathrm{l}$ of SYBR Green Mastermix (Applied Biosystems), a final concentration of $300 \mathrm{nM}$ of

136 forward primer (5'-AGC AAT RCC ATG TGA ACG ATG AA- 3') and an equimolar mixture

137 of two reverse primers (5'-TGG CAC ATA GTT TGC TGT CAC TT-3' and 5'-GCT GGC

138 ACA TAG TTA GCT GTC ACT-3'), and $5 \mu$ of template DNA. After 40 cycles a

139 dissociation run was performed: $95^{\circ} \mathrm{C}$ for $15 \mathrm{~s}, 60^{\circ} \mathrm{C}$ for $20 \mathrm{~s}$, a temperature increase from 60

$140{ }^{\circ} \mathrm{C}$ to $95^{\circ} \mathrm{C}$ in $20 \mathrm{~min}$, and finally $95^{\circ} \mathrm{C}$ for $15 \mathrm{~s}$.

141

142 2.3.4. Species-specific TaqMan PCR for haemotropic mycoplasmas

143

144 Samples that tested positive or gave inconclusive results in the SYBR Green assay were

145 further analyzed. Real-time TaqMan PCR assays specific for the 16S rRNA gene of feline ( $M$.

146 haemofelis, 'Candidatus M. haemominutum', and 'Candidatus M. turicensis'), canine (M.

147 haemocanis, 'Candidatus M. haematoparvum'), and murine haemotropic mycoplasmas ( $M$.

148 coccoides) were performed as previously described (Wengi et al., 2008; Willi et al., 2006;

149 Willi et al, 2007). In addition, for bovine/ovine haemoplasmas (M. wenyonii and M. ovis) a

150 119-bp long fragment of the 16S rRNA gene was amplified (Meli et al., submitted for 
151 publication), involving the forward primer 5'-CCA CGT GAA CGA TGA AGG TCT T-3',

152 the reverse primer 5'-GGC ACA TAG TTA GCT GTC ACT TAT TCA A-3', and the probe

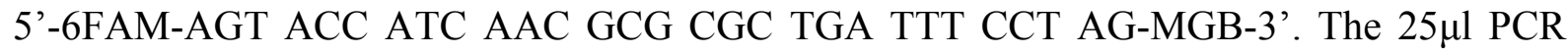

154 MasterMix (Eurogentec, Seraing, Belgium), and $5 \mu \mathrm{l}$ of template DNA.

156 approximately $200 \mathrm{bp}$ region in the 16S rRNA gene of haemoplasmas (Jensen et al., 2001).

\subsubsection{Conventional PCRs for Rickettsia spp.}

Selected gltA TaqMan PCR-positive samples $(\mathrm{n}=19$, with the lowest $\mathrm{Ct}$ values) were further analyzed by a conventional PCR. A 381-bp portion of the gltA gene was amplified using the primers Rp877p and Rp1258n, as previously described (Boretti et al., in press). Additionally, in the case of one sample that gave a sequence different from those deposited in GenBank, a longer gltA gene fragment (796 bp) was amplified with the primers CS477f and CS1273r. Part of the PCR products were stained with ethidium bromide and visualized in agarose gel.

\subsubsection{Conventional PCRs for Mycoplasmatales}

Samples positive in the species-specific TaqMan real-time PCR were further analyzed for the nearly complete 16S rRNA gene as described earlier (Willi et al., 2006). Samples that yielded inconclusive SYBR Green real-time PCR results, but were negative in all species-specific TaqMan assays, were subsequently evaluated with a conventional PCR for a shorter, 
176 After purification of the conventional PCR product with the GenElute ${ }^{\mathrm{TM}}$ PCR Clean-Up Kit

177 (Sigma-Aldrich) and determination of the DNA concentration with the NanoDrop ND-1000

178 spectrophotometer (Witec Ag, Littau, Switzerland), cycle sequencing was performed using

179 the BigDye Terminator Cycle Sequencing Ready Reaction Kit v1.1 (Applied Biosystems).

180 The cycling conditions were as follows: $1 \mathrm{~min}$ at $96{ }^{\circ} \mathrm{C}$, then 25 cycles of $96{ }^{\circ} \mathrm{C}$ for $30 \mathrm{sec}$ 181 and $50{ }^{\circ} \mathrm{C}$ for $15 \mathrm{sec}$, and finally incubation at $60{ }^{\circ} \mathrm{C}$ for $4 \mathrm{~min}$. Products were purified with

182 SigmaSpin ${ }^{\mathrm{TM}}$ Post-Reaction Purification Columns (Sigma-Aldrich), and evaluated on the ABI

183 Prism 310 Genetic Analyzer (Applied Biosystems).

184

185

186

187

188 Pool infection prevalence was calculated from the number of positive pools, expressed as the 189

\subsection{Statistical analysis}

percentage of the number of evaluated pools. Given that there must have been at least one infected individual in each positive pool, the minimum prevalence was determined from the number of positive pools, expressed as the percentage of the number of evaluated arthropod individuals of the species. Confidence intervals (CI) for the prevalence rates at the $95 \%$ level were calculated according to Sterne's method (Reiczigel, 2003).

\subsection{Phylogenetic analyses and nucleotide sequence accession numbers}

Obtained sequences were edited, aligned and compared to reference GenBank sequences as described previously (Hornok et al., 2009). New sequences were submitted to the GenBank, with the accession numbers EU170604 for 'Candidatus Mycoplasma haemominutum', EU170605-15 for Spiroplasma spp., and EU853830-5 plus EU853837-8 for Rickettsia spp. 


\section{Results}

203

204 All extraction and PCR negative controls were negative.

205

\subsection{Rickettsia spp.}

207

208 Using real-time TaqMan PCR for the 23S rRNA gene, $R$. helvetica was detected in 98.5\% 209 (95\% CI: 91.6-100\%) of the H. inermis pools (minimum prevalence 19.7\%; 95\% CI: 15.5 $24.5 \%$ ) (Table 2). A total of $92.6 \%$ (95\% CI: 86.7-96.4\%) of the I. ricinus pools were also

211 shown to be infected (minimum prevalence 7.2\%; 95\% CI: 6-8.5\%). Further two tick species 212 and one flea species were found to harbor $R$. helvetica (Table 2). The minimum prevalence of 213 Rickettsia spp. in D. marginatus and in D. reticulatus was 17.5\% (95\% CI: $13.2-22.5 \%)$ and 214 16\% (95\% CI: 12.3-20.3\%), respectively (Table 2).

215 One pool of $H$. inermis collected in northern Hungary contained a gltA sequence, a 712-bp 216 region of which showed only $95.8 \%$ maximal identity to that of any other known Rickettsia 217 spp. available in the GenBank. Hence the name 'Candidatus R. hungarica' is proposed for this 218 new isolate. In addition, $R$. monacensis was detected in I. ricinus, $R$. slovaca was found in 219 D. marginatus, and $R$. raoultii was identified in D. reticulatus (Table 2). Moreover, 220 'Candidatus R. kotlanii' was shown in an H. concinna pool, and R. felis as well as Rickettsia 221 sp. RF2125 were found in flea pools (Table 2). The phylogenetic relationships of these 222 specimens are depicted in Fig. 1. 


\subsection{Ehrlichia canis}

225

226 Tick pools were evaluated for the presence of E. canis. Two pools of female I. ricinus, both 227 collected in southwestern Hungary, were found to be PCR-positive.

\subsection{Haemotropic Mycoplasma spp.}

All tick pools and the C. canis and P. irritans pools were PCR-negative for haemotropic Mycoplasma spp. Two C. felis pools were positive in the assay specific for 'Candidatus M. haemominutum'; one of them was also found to contain 'Candidatus M. turicensis'. The presence of 'Candidatus M. haemominutum' was also confirmed by sequencing of the $16 \mathrm{~S}$ rRNA gene (EU170604). This isolate showed 100\% identity to a feline isolate recently reported in Hungary (EU128752).

\subsection{Spiroplasma spp.}

240 Fifteen tick pools and four flea pools gave inconclusive results in the real-time SYBR Green 241 assay and were negative in all TaqMan assays designed to detect individual haemoplasma species. Five of the 15 tick pools and three of the four flea pools were found to be negative by

243 conventional PCR. In the remaining pools, representatives of the genus Spiroplasma were 244 found. These included six I. ricinus pools (five female, one nymph), four D. marginatus pools 245 (three male, one female), and one C. felis pool. Sequencing revealed $95-98 \%$ identity to 246 Spiroplasma spp. deposited in GenBank (AJ132412). 


\section{Discussion}

This is the first molecular study of the occurrence of Rickettsia spp., E. canis, haemotropic mycoplasmas and Spiroplasma spp. in questing ticks and in fleas obtained from cats and dogs in Hungary. Since fed (engorged) ticks may harbour infectious agents that were acquired during the blood meal but are irrelevant to their vector potential, only ticks collected from the vegetation were included in the present survey.

Many rickettsiae cause emerging diseases (Hechemy et al., 2006; Brouqui et al., 2007). The geographical distribution of Rickettsia spp. depends on their association with particular tick vectors and animal reservoirs. R. helvetica, a potential human pathogen (Brouqui et al., 2007), is transmitted by I. ricinus in Europe (Parola, 2004) and by other Ixodes spp. in Asia (Fournier et al., 2002). Results of the present study introduce $H$. inermis as a new and significant potential vector of this rickettsia. H. inermis is an emerging species (Hornok and Farkas, 2009), occurring sporadically in most European countries, as well as in the Middle identified for the first time in this study as possible vectors of $R$. helvetica. However, based on the low number of infected pools, they appear to be of only minor importance.

Remarkably, a novel Rickettsia genotype has been found in H. inermis. The difference of at least $4.2 \%$ between the gltA sequences of the new genotype and the sequences of other rickettsiae, argue for its status as a candidate new species ('Candidatus R. hungarica'). For comparison, previous work has estimated the gltA sequence to diverge by up to $2.3 \%$ between members of the SFG group (Regnery et al., 1991). Furthermore, characterization of a shorter, 381-bp portion of the gltA gene has previously been used to describe other new species of the 271 genus (Higgins et al., 1996), and here it showed a minimum of $4.8 \%$ sequence dissimilarity between the new isolate and relevant GenBank sequences. 
PCR positivity for R. slovaca, another clinically important species (Brouqui et al., 2007),

274 has already been detected in two engorged D. marginatus individuals in Hungary (Raoult et al., 2002). The present study extends these findings to unfed ticks. Although only five PCRpositive D. marginatus samples were sequenced, $R$. slovaca was identified in all cases. If we assume that the majority of the PCR-positive D. marginatus pools had been infected with $R$. slovaca, the observed minimum prevalence of $17.5 \%$ is higher than the prevalence of $7.2 \%$ reported previously in this region (Rehácek et al., 1979). Similarly, the sequencing of all five D. reticulatus pools detected $R$. raoultii (formerly Rickettsia sp. RpA4). If we extrapolate this to the remainder of the PCR-positive samples, the high rate of infection in this species is comparable to previous reports evaluating engorged ticks in Hungary (Sréter-Lancz et al., 2006) and Germany (Dautel et al., 2006).

The identification of $R$. monacensis in questing $I$. ricinus and of 'Candidatus $\mathrm{R}$. kotlanii' in

H. concinna in the present study corroborates their earlier detection in engorged specimens (Sréter-Lancz et al., 2006). On the other hand, although the human pathogen R. felis (Higgins et al., 1996) had already been found in Western Europe, both in Germany and France (Rolain et al., 2003), this is the first report of a highly similar sequence from Central-Eastern Europe. Furthermore, Rickettsia sp. RF2125 was shown for the first time in Europe and in the human flea, Pulex irritans; as formerly this species had been identified in Asia, North America, and Africa in C. canis (AF516333), C. felis (AY953289), and Echidnophaga gallinacea (Loftis et al., 2006), respectively.

In Europe, E. canis, the etiological agent of canine monocytic ehrlichiosis, is transmitted by Rh. sanguineus (Groves et al., 1975). This restricts its endemicity to the Mediterranean and 295 Balkanian countries, with prevalences declining towards the north (Solano-Gallego et al., 2006). Recently, however, E. canis was also detected in I. ricinus collected from vegetation in 297 the Netherlands (Wielinga et al., 2006). Since the method used in the present study is highly 
specific for E. canis (Foley et al., 2007) and cross-contamination of the samples is very unlikely, our results raise the possibility of the indigenous status of E. canis in Hungary. However, confirmation of this would require sequencing, which could not have been carried out from the two positive pools due to the low bacterial load.

Vectors of haemotropic mycoplasmas, the causative agents of haemolytic anaemia, may include fleas and hard ticks, as suggested by previous transmission experiments (Seneviratna et al., 1973; Woods et al., 2005). This is further substantiated by the fact that unfed ixodid ticks contained 'Candidatus M. haemominutum' (Taroura et al., 2005). Nevertheless, although haemoplasma infections have been reported in Hungary (Hornok et al., 2008; Hornok et al., 2009), the current study failed to detect PCR positivity in tick pools. This may suggest that

308 ticks do not play a significant role in the transmission of haemotropic mycoplasmas in 309 Hungary, confirming previous results from Switzerland (Willi et al., 2007). On the other hand, feline haemoplasmas are frequently detected in fleas (Willi et al., 2007). Accordingly,

311 'Candidatus M. haemominutum' and 'Candidatus M. turicensis' were found in C. felis, the 312 latter for the first time in Central-Eastern Europe. The 100\% identity of the 16S rRNA gene 313 sequence of the flea isolate with that of one Hungarian cat (EU128752), two Swiss cats 314 (DQ157141, DQ157147), and one UK cat (AF 271154) is consistent with the small genetic 315 differences between haemoplasmas from geographically distant places (Tasker et al., 2003).

316 The genus Spiroplasma has an enormous diversity of often incompletely characterized or 317 unnamed species, including non-pathogenic or symbiotic organisms that persist in insects and 318 arachnids. These bacteria have been associated with transmissible spongiform encephalopathy 319 in humans and ruminants (Bastian et al., 2007), but how they contribute to these diseases remains unclear. Spiroplasmas are found not only in horse flies and mosquitoes, but also in 321 hard ticks (Carle et al., 1995). In particular, I. ricinus from Germany (Henning et al., 2006) 322 and Haemaphysalis spp. (Carle et al., 1995) have been reported to be carriers of these agents. 
342 Bastian, F.O., Sanders, D.E., Forbes, W.A., Hagius, S.D., Walker, J.V., Henk, W.G., Enright,

343 F.M., Elzer, P.H., 2007. Spiroplasma spp. from transmissible spongiform encephalopathy

344 brains or ticks induce spongiform encephalopathy in ruminants. J. Med. Microbiol. 56, 1235345 1242. 
347 Boretti, F.S., Perreten, A., Meli, M.L., Cattori, V., Willi, B., Wengi, N., Hornok, S.,

348 Honegger, H., Hegglin, D., Woelfel, R., Reusch, C.E., Lutz, H., Hofmann-Lehmann, R. 2009.

349 Molecular investigations of Rickettsia helvetica infection in dogs, foxes, humans and Ixodes 350 spp. ticks. Appl. Environ. Microbiol., in press.

352 Brouqui, P., Parola, P., Fournier, P.-E., Raoult, D., 2007. Spotted fever rickettsioses in 353 southern and eastern Europe. FEMS Immunol. Med. Microbiol. 49, 2-12.

355 Carle, P., Laigret, F., Tully, J.G., Bové, J.M., 1995. Heterogeneity of genome sizes within the 356 genus Spiroplasma. Int. J. Syst. Bacteriol. 45, 178-181.

Dautel, H., Dippel, C., Oehme, R., Hartelt, K., Schettler, E., 2006. Evidence for an increased geographical distribution of Dermacentor reticulatus in Germany and detection of Rickettsia sp. RpA4. Int. J. Med. Microbiol. 296 S1, 149-156.

362 Dumler, J.S., Barbet, A.F., Bekker, C.P.J., Dasch, G.A., Palmer, G.H., Ray, S.C., Rikihisa, 363 Y., Rurangirwa, F.R., 2001. Reorganization of genera in the families Rickettsiaceae and 364 Anaplasmataceae in the order Rickettsiales: unification of some species of Ehrlichia with Anaplasma, Cowdria with Ehrlichia and Ehrlichia with Neorickettsia, descriptions of six new species combinations and designation of Ehrlichia equi and 'HGE agent' as subjective synonyms of Ehrlichia phagocytophila. Int. J. Syst. Evol. Micr. 51, 2145-2165.

Foley, J., Drazenovich, N., Leutenegger, C.M., Chomel, B.B., 2007. Association between polyarthritis and thrombocytopenia and increased prevalence of vectorborne pathogens in Californian dogs. Vet. Rec. 160, 159-162. 
373 Fournier, P.-E., Fujita, H., Takada, N., Raoult, D., 2002. Genetic identification of rickettsiae

374 isolated from ticks in Japan. J. Clin. Microbiol. 40, 2176-2181.

375

376 Groves, M.G., Dennis, G.L., Amyx, H.L., Huxsoll, D.L., 1975. Transmission of Ehrlichia 377 canis to dogs by ticks (Rhipicephalus sanguineus). Am. J. Vet. Res. 36, 937-940.

Hechemy, K.E., Oteo, J.A., Raoult, D., Silverman, D.J., Blanco, J.R., 2006. A century of 380 rickettsiology: emerging, reemerging rickettsioses, clinical, epidemiologic, and molecular 381 diagnostic aspects and emerging veterinary rickettsioses: an overview. Ann. N. Y. Acad. Sci. $3821078,1-14$

Henning, K., Greiner-Fischer, S., Hotzel, H., Ebsen, M., Theegarten, D., 2006. Isolation of Spiroplasma sp. from an Ixodes tick. Int. J. Med. Microbiol. 296 S1, 157-161.

Higgins, J.A., Radulovic, S., Schriefer, M.E., Azad, A.F., 1996. Rickettsia felis: a new species of pathogenic rickettsia isolated from cat fleas. J. Clin. Microbiol. 34, 671-674.

Hornok, S., Meli, M.L., Gönczi, E., Ignits, É., Willi, B., Lutz, H., Hofmann-Lehmann, R., 2008. First molecular identification of 'Candidatus mycoplasma haemominutum' from a cat with fatal haemolytic anaemia in Hungary. Acta Vet. Hung. 56, 441-450. questing ixodid ticks in Hungary. Med. Vet. Entomol. 23, 41-46. 
Hornok, S., Meli, M.L., Erdős, A., Hajtós, I., Lutz, H., Hofmann-Lehmann, R. 2009.

398 Molecular characterization of two different strains of haemotropic mycoplasmas from a sheep

399 flock with fatal haemolytic anaemia and concomitant Anaplasma ovis infection. Vet.

400 Microbiol., in press.

401

402 Jensen, W.A., Lappin, M.R., Kamkar, S., Reagan, W.J., 2001. Use of a polymerase chain 403 reaction assay to detect and differentiate two strains of Haemobartonella felis in naturally 404 infected cats. Am. J. Vet. Res. 62, 604-608.

405

406 Loftis, A.D., Reeves, W.K., Szumlas, D.E., Abbassy, M.M., Helmy, I.M., Moriarity, J.R., 407 Dasch, G.A., 2006. Surveillance of Egyptian fleas for agents of public health significance: 408 Anaplasma, Bartonella, Coxiella, Ehrlichia, Rickettsia, and Yersinia pestis. Am. J. Trop. 409 Med. Hyg. 75, 41-48.

410

411 Neimark, H., Johansson, K.-E., Rikihisa, Y., Tully, J.G., 2001. Proposal to transfer some 412 members of the genera Haemobartonella and Eperythrozoon to the genus Mycoplasma with 413 descriptions of 'Candidatus Mycoplasma haemofelis', 'Candidatus Mycoplasma 414 haemomuris', 'Candidatus Mycoplasma haemosuis' and 'Candidatus Mycoplasma 415 wenyonii'. Int. J. Syst. Evol. Micr. 51, 891-899.

416

417 Parola, P. 2004. Tick-borne rickettsial diseases: emerging risks in Europe. Comp. Immunol. 418 Microbiol. Infect. Dis. 27, 297-304.

419 
Raoult, D., Lakos, A., Fenollar, F., Beytout, J., Brouqui, P., Fournier, P.-E., 2002. Spotless rickettsiosis caused by Rickettsia slovaca and associated with Dermacentor ticks. Clin. Infect. Dis. 34, 1331-1336.

Regnery, R.L., Spruill, C.L., Plikaytis, B.D., 1991. Genotypic identification of rickettsiae and estimation of intraspecies sequence divergence for portions of two rickettsial genes. J. Bacteriol. 173, 1576-1589.

Rehácek, J., Nosek, J., Úrvölgyi, J., Sztankay, M., 1979. Rickettsiae of the spotted fever group in Hungary. Folia Parasit. 26, 367-371.

Reiczigel, J. 2003. Confidence intervals for the binomial parameter: some new considerations. Stat. Med. 22, 611-621.

Rolain, J.-M., Franc, M., Davoust, B., Raoult, D., 2003. Molecular detection of Bartonella quintana, B. koehlerae, B. henselae, B. clarridgeiae, Rickettsia felis, and Wolbachia pipientis in cat fleas, France. Emerg. Infect. Dis. 9, 338-342.

Seneviratna, P., Weerasinghe, N., Ariyadasa, S., 1973. Transmission of Haemobartonella canis by the dog tick, Rhipicephalus sanguineus. Res. Vet. Sci. 14, 112-114.

Solano-Gallego, L., Trotta, M., Razia, L., Furlanello, T., Caldin, M., 2006. Molecular survey of Ehrlichia canis and Anaplasma phagocytophilum from blood of dogs in Italy. Ann. N. Y. Acad. Sci. 1078, 515-518. 
445 Sréter-Lancz, Z., Széll, Z., Kovács, G., Egyed, L., Márialigeti, K., Sréter, T., 2006. 446 Rickettsiae of the spotted-fever group in ixodid ticks from Hungary: identification of a new 447 genotype ('Candidatus Rickettsia kotlanii'). Ann. Trop. Med. Parasitol. 100, 229-236.

Taroura, S., Shimada, Y., Sakata, Y., Miyama, T., Hiraoka, H., Watanabe, M., Itamoto, K.,

450 Okuda, M., Inokuma, H., 2005. Detection of DNA of 'Candidatus Mycoplasma

451 haemominutum' and Spiroplasma sp. in unfed ticks collected from vegetation in Japan. J. Vet.

452 Med. Sci. 67, 1277-1279.

Tasker, S., Helps, C.R., Day, M.J., Harbour, D.A., Shaw, S.E., Harrus, S., Baneth, G., Lobetti,

R.G., Malik, R., Beaufils, J.P., Belford, C.R., Gruffydd-Jones, T.J., 2003. Phylogenetic analysis of Hemoplasma species: an international study. J. Clin. Microbiol. 41, 3877-3880.

Wengi, N., Willi, B., Boretti, F.S., Cattori, V., Riond, B., Meli, M.L., Reusch, C.E., Lutz, H.,

Hofmann-Lehmann, R., 2008. Real-time PCR-based prevalence study, infection follow-up

460 and molecular characterization of canine haemotropic mycoplasmas. Vet. Microbiol. 126, $461 \quad 132-141$.

462

463 Wielinga, P.R., Gaasenbeek, C., Fonville, M., Boer, A. de, Vries, A. de, Dimmers, W., 464 Akkerhuis Op Jagers, G., Schouls, L.M., Borgsteede, F., Giessen, J. W. B. van der, 2006. 465 Longitudinal analysis of tick densities and Borrelia, Anaplasma, and Ehrlichia infections of 466 Ixodes ricinus ticks in different habitat areas in The Netherlands. Appl. Environ. Microbiol. $467 \quad 72,7594-7601$. 
469 Willi, B., Boretti, F.S., Baumgartner, C., Tasker, S., Wenger, B., Cattori, V., Meli, M.L.,

470 Reusch, C.E., Lutz, H., Hofmann-Lehmann, R., 2006. Prevalence, risk factor analysis, and

471 follow-up of infections caused by three feline hemoplasma species in cats in Switzerland. J.

472 Clin. Microbiol. 44, 961-969.

473

474 Willi, B., Boretti, F.S., Meli, M.L., Bernasconi, M.V., Casati, S., Hegglin, D., Puorger, M.,

475 Neimark, H., Cattori, V., Wengi, N., Reusch, C.E., Lutz, H., Hofmann-Lehmann, R., 2007.

476 Real-time PCR investigation of potential vectors, reservoirs, and shedding patterns of feline

477 hemotropic mycoplasmas. Appl. Environ. Microb. 73, 3798-3802.

478

479 Woods, J.E., Brewer, M.M., Hawley, J.R., Wisnewski, N., Lappin, M.R., 2005. Evaluation of

480 experimental transmission of 'Candidatus Mycoplasma haemominutum' and Mycoplasma

481 haemofelis by Ctenocephalides felis to cats. Am. J. Vet. Res. 66, 1008-1012.

482 


\section{Figure caption:}

484

485 Figure 1. A bootstrap phylogenetic tree of the gltA gene demonstrating the relationship of 486 Hungarian isolates to other Rickettsia spp. using the Neighbor-Joining method. The numbers 487 at the nodes were generated from 1,000 Bootstrap resamplings. The scale bar represents the 488 mean number of differences per 50 sites. 


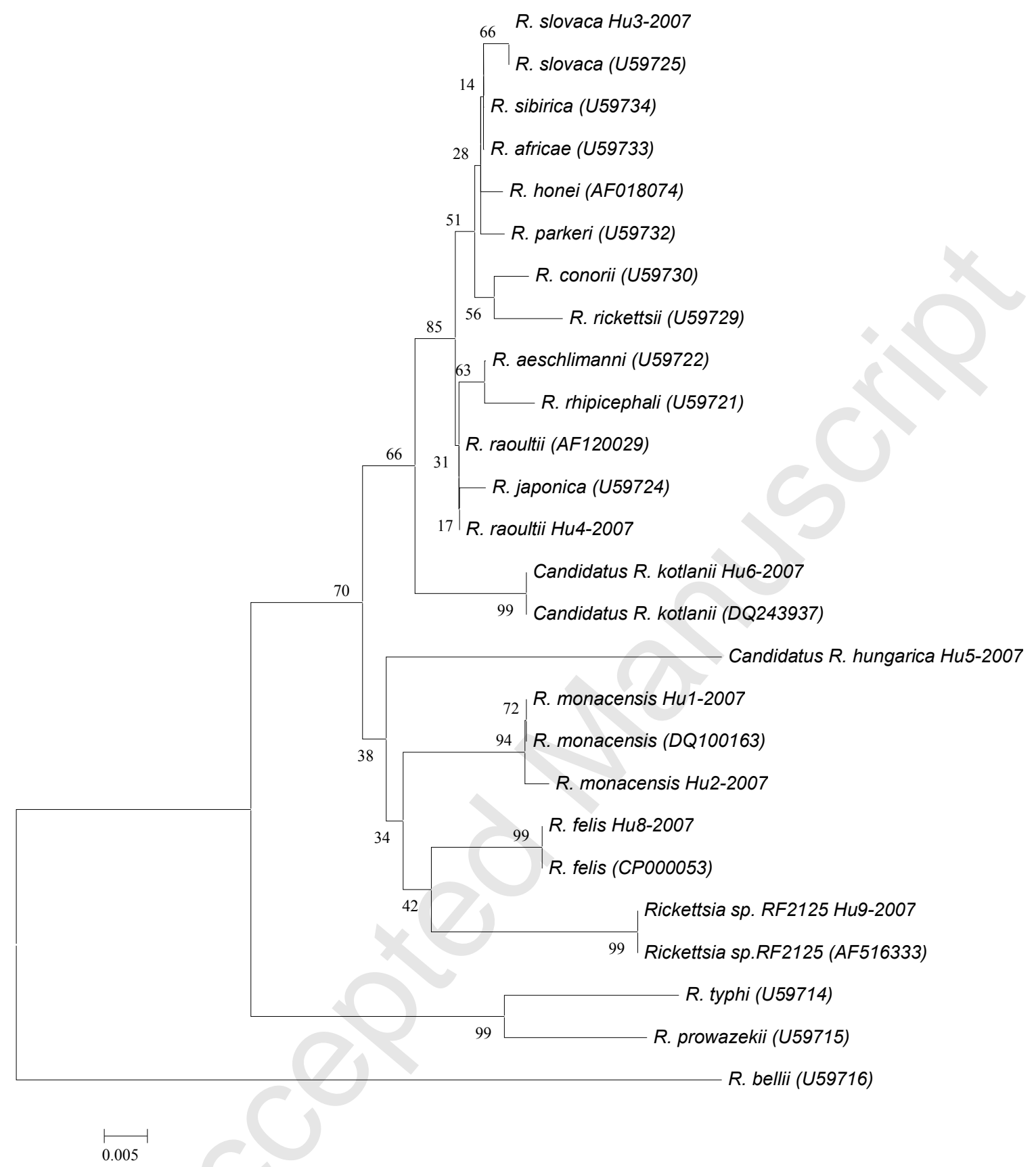


Table 1. Pooling criteria for ticks and fleas.

\begin{tabular}{|c|c|c|c|c|}
\hline & $\begin{array}{l}\text { Total } \\
\text { number }\end{array}$ & $\begin{array}{l}\text { Number of adults } \\
\text { per pool }\end{array}$ & $\begin{array}{l}\text { Number of immature } \\
\text { stages per pool }^{1}\end{array}$ & $\begin{array}{l}\text { Total number of } \\
\text { pools }\end{array}$ \\
\hline Ticks & 3442 & & & \\
\hline Ixodes ricinus & 2116 & $20 \hat{\partial}, 10$ ㅇ & $30 \mathrm{n}, 241$ & $41 \hat{\jmath}, 94$ ᄋ, 9 n, 11 \\
\hline Dermacentor marginatus & 369 & $5 \circlearrowleft, 5 q$ & - & $23 \hat{\sigma}, 34$ o \\
\hline D. reticulatus & 361 & $5 \hat{0}, 5$ P & - & $25 \hat{o}^{\lambda}, 46$ ㅇ \\
\hline Haemaphysalis inermis & 315 & $5 \delta^{\lambda}, 5 q$ & - & $24 \hat{\delta}, 40$ q \\
\hline H. concinna & 259 & $3 \hat{0}, 3$ ㅇ & $10 \mathrm{n}, 521$ & $29 \widehat{\sigma}, 16 \stackrel{q}{ }, 7 \mathrm{n}, 11$ \\
\hline H. punctata & 22 & $3 \delta^{\lambda}, 3$ & $1 \mathrm{n}$ & $5 \sigma^{\lambda}, 3+, 1 \mathrm{n}$ \\
\hline Fleas & 939 & & & \\
\hline Ctenocephalides felis & 393 & $1-11$ & - & 187 \\
\hline C. canis & 526 & $1-12$ & - & 195 \\
\hline Pulex irritans & 20 & $1-4$ & - & 15 \\
\hline
\end{tabular}

TAbbreviations: n, nymph; 1, larva 
Table 2. Real-time PCR and sequencing results of Rickettsia spp. in hard ticks (Ixodidae) and fleas (Ctenocephalidae, Pulicidae). Except for Ixodes ricinus and Ctenocephalides felis, only samples negative for the 23S rRNA gene were evaluated in the gltA gene TaqMan assay.

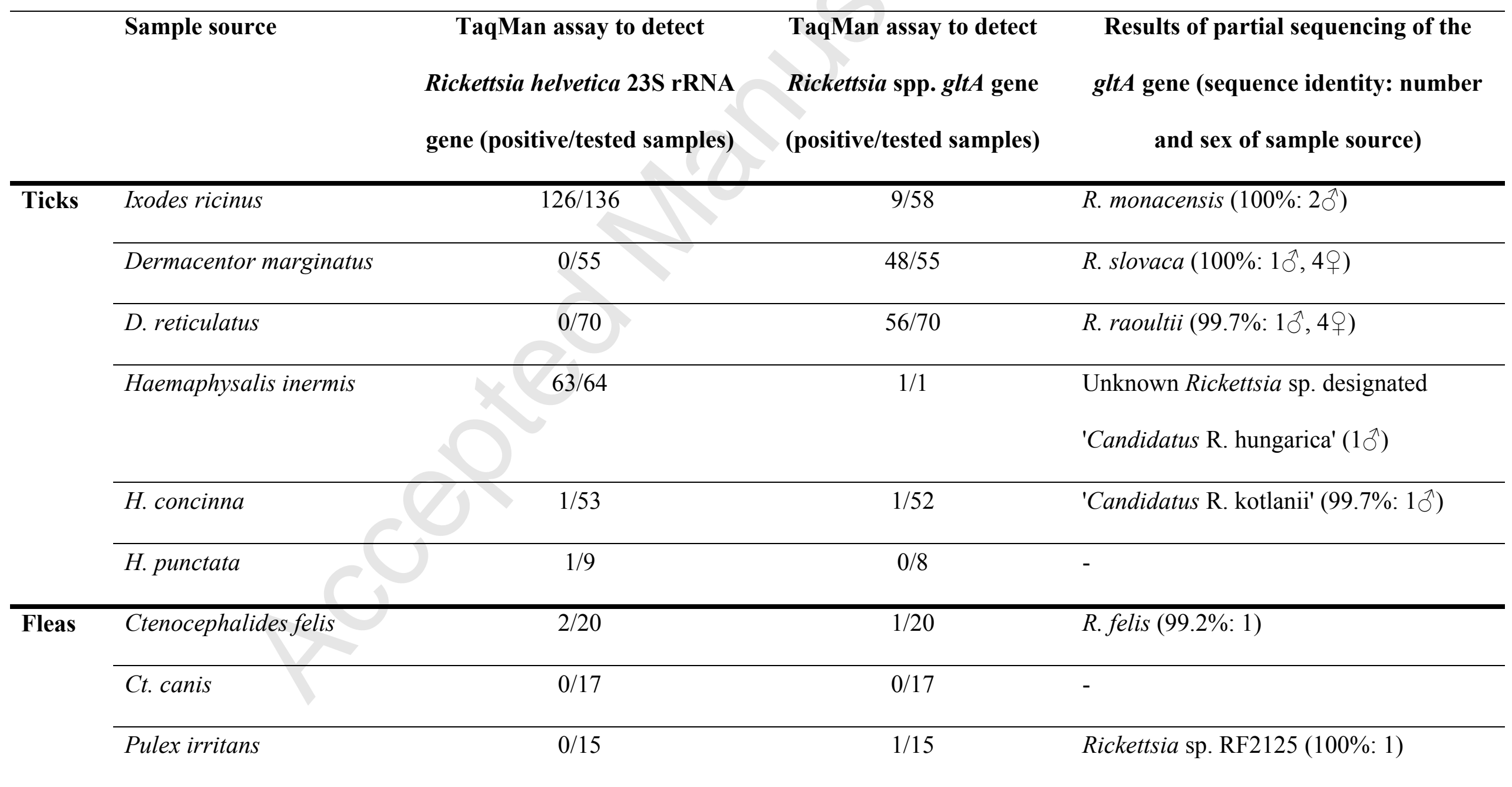

